\title{
Roles of Nucleus Accumbens CREB and Dynorphin in Dysregulation of Motivation
}

\author{
John W. Muschamp and William A. Carlezon, Jr. \\ Behavioral Genetics Laboratory, Department of Psychiatry, Harvard Medical School, McLean Hospital, \\ Belmont, Massachusetts 02478 \\ Correspondence: bcarlezon@mclean.harvard.edu
}

Psychostimulants such as amphetamine and cocaine are believed to produce dependence by causing rapid, supraphysiological elevations in synaptic dopamine (DA) within the nucleus accumbens (NAc) (Volkow et al. 2009, Neuropharmacology 56: 3-8). These changes in forebrain DA transmission are similar to those evoked by natural reinforcers (Louilot et al. 1991, Brain Res 553: 313-317; Roitman et al. 2004, J Neurosci 24: 1265-1271), but are of greater magnitude and longer duration. Repeated drug exposure causes compensatory neuroadaptations in neurons of the NAc, some of which may modulate excess DA in a homeostatic fashion. One such adaptation is the activation of the transcription factor CREB (cAMP response element-binding protein) within neurons of the NAc. Although elevated levels of transcriptionally active CREB appear to attenuate DA transmission by increasing expression of the endogenous $\kappa$ opioid receptor (KOR) ligand dynorphin, increased dynorphin transmission may ultimately have undesirable effects that contribute to drug withdrawal states as well as comorbid psychiatric illnesses such as depression. This state may prompt a return to drug use to mitigate the adverse effects of withdrawal. This article summarizes our current understanding of how CREB and dynorphin contribute to the dysregulation of motivation and describes novel therapeutic strategies that derive from preclinical research in this area.

\begin{abstract}
$A^{\text {lthough the exact nature of its role contin- }}$ Aues to be refined in the literature, there is broad agreement on the importance of nucleus accumbens (NAc) dopamine (DA) in addiction, particularly to psychostimulants. Indeed, rodents will self-administer these drugs directly into the NAc, where they elevate extracellular DA by actions on transporter proteins in vesicles or the presynaptic membrane (Hoebel et al. 1983; Carlezon et al. 1995; Ikemoto and Wise 2004). It is outside the scope of this article to review this extensive literature, but a few key
\end{abstract}

details provide perspective. The NAc is critically involved in motivation and emotion (i.e., the affective states that typically accompany motivated behavior). Although the dorsolateral aspect of the striatum receives projections from the sensorimotor cortex, the ventromedial regions, including the NAc, receive afferents from the prefrontal cortex as well as limbic structures like the amygdala and hippocampus (Voorn et al. 2004). The NAc thus exists at a "limbic-motor interface" and integrates memory with affectively valenced input from the

Editors: R. Christopher Pierce and Paul J. Kenny

Additional Perspectives on Addiction available at www.perspectivesinmedicine.org

Copyright (C) 2013 Cold Spring Harbor Laboratory Press; all rights reserved; doi: 10.1101/cshperspect.a012005

Cite this article as Cold Spring Harb Perspect Med 2013;3:a012005 
J.W. Muschamp and W.A. Carlezon, Jr.

amygdala and contextual information from the hippocampus (Mogenson et al. 1980). It may then coordinate appropriate goal-directed behavioral responses by recruiting elements of the basal ganglia that are critical for motor output (Groenewegen et al. 1996; Pennartz et al. 2009; Redgrave et al. 2011). The role of DA in this process is facilitative with regard to acute locomotor activation (Jackson et al. 1975; Ikemoto and Panksepp 1999), but DA is also important for reward learning in which it also fulfills a facilitative role (Wise 2004). For instance, rats will perform an operant (nosepoke response) to selectively stimulate their midbrain DA neurons (Witten et al. 2011). This circuitry likely evolved to process information about biological reinforcers and the cues that predict them. Drugs of abuse "co-opt" this circuitry (Kauer and Malenka 2007), such that over time the ability of drugs and drug-related cues to influence behavior becomes stronger, whereas the significance of natural reinforcers weakens (Chambers et al. 2007).

Although NAc DA is critical for behavioral output, the extent to which it encodes distinct affective states is uncertain, because DA transmission can increase in response to both rewarding and aversive stimuli (Joseph et al. 2003; Schultz 2007; Brischoux et al. 2009). It seems plausible, however, that hypodopaminergic states observed during withdrawal from chronic psychostimulant exposure represent an important component of the mechanism underlying the dysphoria and anergia that accompany withdrawal (Weddington et al. 1990; Parsons et al. 1991; Robertson et al. 1991; Coffey et al. 2000). Within the NAc, DA regulates the excitability of GABAergic medium spiny neurons (MSNs), the predominant ( 95\%) type of cell within this structure (Meredith 1999). Studies in awake, freely moving rats show that MSNs respond to the hedonic valence of external stimuli by altering their firing rate (Roitman et al. 2005), leading to theories of how affective states of reward and aversion may be encoded in the activity of these neurons (Carlezon and Thomas 2009). Interactions among neuronal activity, intracellular signaling cascades, and transcriptionally active molecules such as CREB play key roles in translating experience into molecular adaptations that can influence the behavior of an organism for its lifespan.

\section{CREB-MEDIATED TRANSCRIPTIONAL ACTIVATION}

Neurons are among the most transcriptionally active cells in the body. This is clear not only from modern expression profiling techniques (Okaty et al. 2011), but also from casual inspection of neuronal ultrastructure that typically includes a large, round nucleus containing a high proportion of euchromatin. High transcriptional activity is required for neurons to integrate a complex array of chemical signals and respond appropriately with lasting changes in gene expression that can influence various cellular properties like electrical excitability and dendritic morphology (Hobert et al. 2010). The extracellular signals that stimulate these changes do so by using second messenger cascades to recruit transcription factors that interact directly with genomic DNA.

CREB is a ubiquitously expressed nuclear protein that allows stimulus-dependent regulation of transcriptional activity in postsynaptic neurons (Fig. 1) (Montminy and Bilezikjian 1987; Shaywitz and Greenberg 1999). The formation of CREB dimers at 8-bp consensus sequences called cAMP response elements (CREs) is the first step in transcriptional activation (Montminy et al. 1986; Yamamoto et al. 1988). In contrast, CREB transcription may be attenuated by dimer formation between CREB and other proteins that contain the leucine zipper protein interaction motif but lack a CRE-binding domain (e.g., cAMP response element modulator, CREM) (Foulkes et al. 1991). The traditional view has been that CREB-regulated genes contain CREs located in promoters near the transcriptional start, but recent work suggests that CREB can also exert its effects at CREs in more distally situated enhancer elements (Kim et al. 2010). Another requirement for CREB transcription is association with CREB-binding protein $(\mathrm{CBP})$, which has histone deacetylase activity that is necessary to decondense 


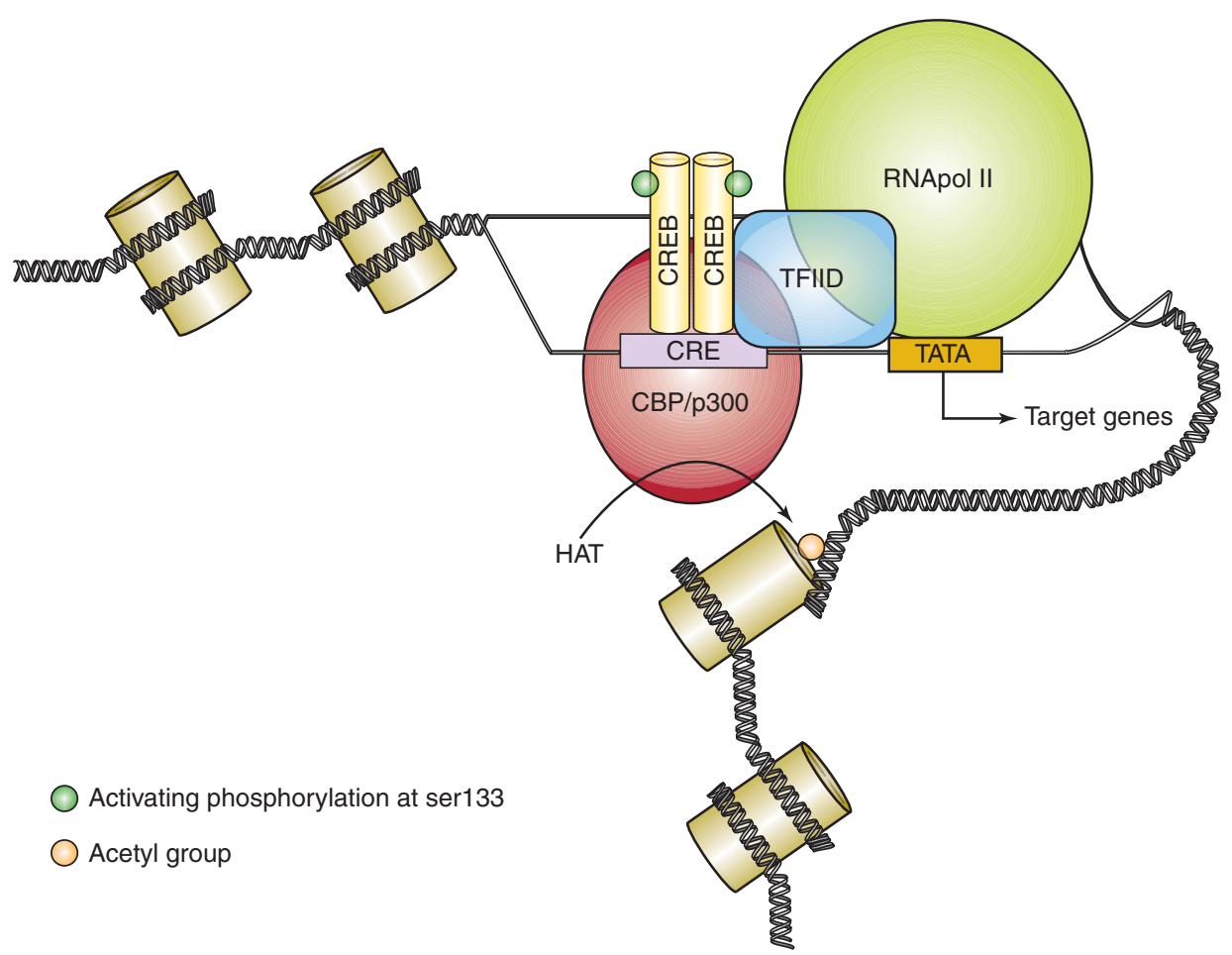

Figure 1. Simplified depiction of the CREB-mediated gene transcription cascade. CREB dimers bind to a cAMP response element (CRE) in the promoter region of target genes. On phosphorylation at ser133, pCREB dimers interact with binding proteins (e.g., CBP/p300) and stimulate histone acetyltransferase (HAT) activity. Histone acetylation permits loosening of chromatin and formation of a transcriptional complex, enabling transcription of CREB target genes. Mutant forms of CREB that are resistant to phosphorylation at ser133 (e.g., mCREB) bind to CREs but do not trigger this cascade, resulting in blockade of endogenous pCREB and disruption of gene transcription.

chromatin and enable the transcriptional complex access to DNA (Chrivia et al. 1993; Bannister and Kouzarides 1996; Ogryzko et al. 1996). The association between CREB and CBP follows phosphorylation of CREB at a conserved serine residue in position 133 (Gonzalez and Montminy 1989; Radhakrishnan et al. 1997). Although the term "pCREB" is often used as shorthand for CREB phosphorylated at ser133, which is transcriptionally active, phosphorylation at other residues can also affect CREB activity (see below, and Carlezon et al. 2005). Characterization of this mechanism has enabled the development of mutant forms of CREB including one (i.e., mCREB/CREB-M1) with a serine to alanine substitution at residue 133, which prevents phosphorylation (Gonzalez and
Montminy 1989). As described below, mCREB functions as dominant negative- a defective form of the protein that blocks the normal (wild-type) form of the protein-which has enabled the design of experiments in which CREB function is disrupted in discrete brain structures (e.g., Carlezon et al. 1998). Once pCREB dimers bind to CRE sequences, and CBP acetylates histones, CREB binds to a TATA Binding Protein (TBP)-associated factor protein (TAF4) within transcription factor 2D (TFIID), an essential part of the preinitiation complex that binds to gene promoter regions with very high affinity and activates RNA polymerase II (Ferreri et al. 1994; Kee et al. 1996; Papai et al. 2011). These complex interactions are all necessary for transcription of CREB-regulated target genes. 
J.W. Muschamp and W.A. Carlezon, Jr.

\section{MECHANISMS OF CREB INDUCTION AND ACTIVATION}

\section{Intracellular Signals}

Multiple signaling pathways converge on CREB to drive gene transcription (Fig. 2). Effects on transcription can be pathway specific. For example, CREB phosphorylation at ser133 via stimulation of CAMP-dependent protein kinase (PKA), calcium/calmodulin-dependent kinase IV (CaMKIV), or ribosomal S6 kinase activate transcription (see Carlezon et al. 2005). In contrast, CREB phosphorylation at ser 142 by CaMKII inhibits the interaction between CREB and CBP, resulting in transcriptional repression (Sun et al. 1994; Loweth et al. 2010).
Additional modulators of CREB function have been identified. One such class of proteins is cAMP-regulated transcriptional coactivators (CRTCs) like transducer of regulated CREB-1 (TORC1) (Conkright et al. 2003; Altarejos and Montminy 2011). When dephosphorylated and exposed to conditions of high cAMP or $\mathrm{Ca}^{2+}$, TORC1 translocates to the nucleus and binds to CREB, enhancing transcriptional activity. It was recently shown that microRNA-mediated expression of TORC1 can reduce cocaine self-administration by enhancing CREB signaling in striatal regions (Hollander et al. 2010). Other modulators of CREB function (e.g., CREM; inducible cAMP early repressor, ICER) have received comparatively less scrutiny than CREB

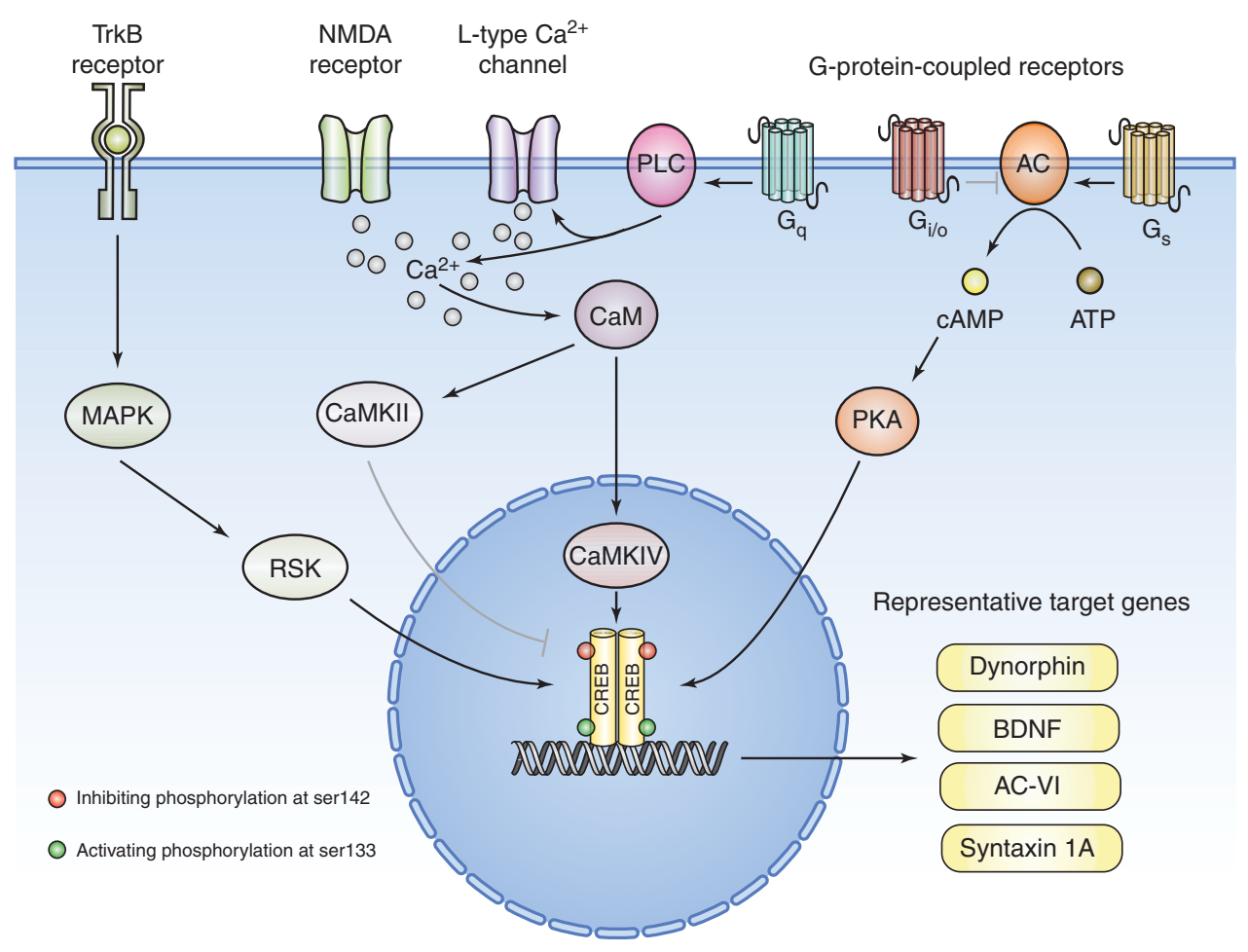

Figure 2. Simplified depiction of how extracellular signals influence gene transcription via CREB. Phosphorylation of CREB at ser133 increases its transcriptional activity and target gene expression. CREB activity can be attenuated by phosphorylation of CREB at ser142. Within the NAc, neurons expressing $\mathrm{G}_{\mathrm{s}}$-coupled receptors (e.g., dopamine $D_{1}$ ) activate adenylate cyclase $(A C)$, whereas neurons expressing the $G_{i / o}$-coupled receptors (e.g., dopamine $\mathrm{D}_{2}$ ) inhibit AC. Exposure to psychostimulants can also trigger activation of MAPK- and calcium $\left(\mathrm{Ca}^{2+}\right)$-sensitive signal transduction pathways. For clarity, cross talk between second messengers is not included. Black lines signify activation; gray lines signify inhibition. 
in the context of drug addiction, but recent work suggests that ICER may impair enhanced locomotor activation in response to repeated methamphetamine exposure (behavioral sensitization) (Molina et al. 1993; Han et al. 2011).

The timescale for CREB activation by many of these signaling pathways is believed to be on the order of minutes; as one example, pCREB levels peak about $30 \mathrm{~min}$ after adenylate cyclase (AC) stimulation (Hagiwara et al. 1993). The rate-limiting step in this process may be the passive diffusion of cytosolic proteins (e.g., catalytic subunits of protein kinase [PKA]) into the nucleus. After peak activation, pCREB levels then decrease gradually over hours as it is inactivated by protein phosphatases 1 and $2 \mathrm{~A}$ (Hagiwara et al. 1992; Wadzinski et al. 1993). In this relatively short time window $(<18-$ $20 \mathrm{~h}$ ), however, CREB can orchestrate profound changes in neuronal transcriptomes that in turn cause significant alterations in the physiology of individual cells as well as the circuits in which they are embedded.

\section{Extracellular Signals and Organismal Stimuli}

Extracellular stimuli that recruit various second messenger cascades can induce CREB activation. An increase in extracellular DA induced by drugs like cocaine and amphetamine is one such stimulus that reliably induces CREB phosphorylation in the NAc (Turgeon et al. 1997). Experiments using selective $\mathrm{D}_{1}$ receptor ligands suggest that this effect is the result of DA activating this subtype of $\mathrm{G}_{\mathrm{s}}$-coupled receptor (Liu and Graybiel 1998). More recent work, however, suggests that the ERK pathway may also be important (Mattson et al. 2005). This can also be inferred from cocaine-induced elevations in brain-derived neurotrophic factor (BDNF)TrkB receptor signaling (Graham et al. 2007). These investigators report that enhanced TrkB signaling is an important mediator of relapse to cocaine self-administration in rats undergoing withdrawal.

Stress and stress-associated psychiatric syndromes such as major depression and posttraumatic stress disorder (PTSD) are frequently comorbid with addiction, and play a particularly prominent role in triggering relapse to drug use in abstinent former users (Swendsen et al. 2010). Addiction researchers have sought to understand this relationship by identifying neuroadaptations that are common to drug exposure and stress. One common neuroadaptation in animal models is CREB activation in the NAc. Both noxious stressors and aversive stimuli (e.g., forced swim or social stress, FST) are responsible for enhanced CREB phosphorylation, possibly by elevating synaptic DA in NAc and subsequent recruitment of the cAMP/PKA pathway (Tidey and Miczek 1996; Pliakas et al. 2001; Wilkinson et al. 2009; Muschamp et al. 2011). Like cocaine, stress may also activate CREB via BDNF stimulation of the ERK pathway (Covington et al. 2011).

\section{CELLULAR AND MOLECULAR CONSEQUENCES OF CREB ACTIVATION}

CREs are found widely throughout mammalian genomes. CREB is capable of regulating the expression of thousands of genes (Impey et al. 2004; Zhang et al. 2005), but there are important factors that constrain the number of genes whose expression can be directly influenced by CREB. For example, nucleotides that make up CREs may be methylated or otherwise unavailable for CREB binding. Additionally, CREs may not be located proximal ( $~ 250 \mathrm{bp}$ ) to transcriptional start sites for a particular gene, thus limiting the ability of CREB to couple the transcriptional complex to its locus of action in a target gene (Mayr and Montminy 2001). Layered on top of these fundamental constraints on the CREB-mediated transcriptome are those that are specific to a given cell type and its immediate extracellular signaling milieu. The presence or absence of various cell-surface receptors, their associated signaling cascades, and the action of different CREB modulators further shortens the list of genes that are potentially regulated by CREB. Considering these factors, predicting a set of target genes from primary sequence data is difficult. Ultimately, this information must be determined empirically by using in vitro or in vivo techniques. 
J.W. Muschamp and W.A. Carlezon, Jr.

Expression profiling of tissue from the NAc by microarray has identified $>100$ genes that are up-regulated by CREB overexpression (McClung and Nestler 2003). Among them are genes involved in synaptic transmission (e.g., syntaxin 1A), intracellular signaling (e.g., AC VI), cell growth (e.g., BDNF), as well as other transcriptionally active proteins like c-Fos, which multiplies the number of potential target genes CREB can influence. The functional effects of these CREB-induced gene products and their behavioral relevance require careful characterization. One strategy has been to use viralmediated gene transfer as a tool for manipulating CREB expression in NAc and other brain structures implicated in drug reward and stress. An early concern when using viral vectors to elevate CREB levels was that this approach would create an unintended dominant-negative effect by overwhelming the ability of a transduced cell to phosphorylate all available CREB, resulting in blockade of pCREB dimer binding at CREs by unphosphorylated CREB dimers. Work showing increased transcription of known CREB-regulated target genes and opposite effects of dominant-negative forms of CREB (Carlezon et al. 1998) established that elevated CREB levels result in elevated CREB activity. This technique was subsequently combined with slice physiology to assess how elevated CREB activity affects the electrophysiological properties MSNs in the NAc (Dong et al. 2006). When infected with viral constructs encoding CREB, MSNs show marked increases in excitability, showing an $\sim 35 \%$ mean increase in the number of action potentials evoked by current injection. Expression of $\mathrm{MCREB}$ produced opposite effects, causing reductions in excitability. In a related study, the same gene transfer technique was used to show that elevated CREB prolongs the duration of depolarized "up-states" in MSNs (Huang et al. 2008), an effect that may be due to CREB-mediated induction of the NR1 subunit of the N-methyl-Daspartate (NMDA) receptor and its incorporation into functional $N$-methyl-D-aspartate receptors (NMDARs) at the cell surface. Together these findings suggest that a major cellular effect of CREB on NAc cell physiology is to increase firing probability and thus excitability. Increased excitability in this structure could play a key role in influencing reward processing and affective state in the context of drug addiction (Carlezon and Thomas 2009).

Regulation of genes that encode excitatory neurotransmitter receptors is one way that CREB can influence network activity in the NAc and structures that receive its projections. Another way is by the induction of genes for peptide neuromodulators that fulfill an important signaling role in this circuit. One of these genes encodes enkephalin, the endogenous transmitter at $\delta$ opioid receptors. Enkephalin is found in $\mathrm{D}_{2}$ receptor-expressing striatopallidal neurons of the "indirect pathway" (Gerfen and Surmeier 2011). In these neurons, CREB enhances the expression of enkephalin (Konradi et al. 1993; Kobierski et al. 1999). This can be shown by treatment with the $\mathrm{D}_{2}$ antagonist haloperidol, which results in disinhibition of AC and CREB phosphorylation, presumably by PKA because the $D_{2}$ receptor is coupled to the $\mathrm{G}_{\mathrm{i}}$ protein.

CREB can also induce the expression of dynorphin (Daunais et al. 1995; Simpson and McGinty 1995; Carlezon et al. 1998), the endogenous agonist at $\kappa$ opioid receptors (KORs) (Chavkin et al. 1982). Dynorphin is coexpressed in $\mathrm{D}_{1}$-expressing striatonigral neurons of the "direct pathway," so CREB effects on dynorphin levels in these neurons should be secondary to $\mathrm{D}_{1}$ activation and recruitment of PKA (Gerfen and Surmeier 2011). Support of this view comes from experiments in cultured striatal neurons in which DA or the AC activator forskolin both caused large increases (two- or sevenfold, respectively) in prodynorphin messenger RNA (mRNA) (Cole et al. 1995). Gel supershift assays showed that this effect required binding of pCREB to three CRE sequences in the prodynorphin promoter, and that PCREB could be induced by treatment with $\mathrm{D}_{1}$ but not $\mathrm{D}_{2}$ agonists. In experiments that mirror those performed with $\mathrm{D}_{2}$-selective drugs and enkephalin expression, a $\mathrm{D}_{1} / \mathrm{PKA}$ initiated, CREB-dependent process of dynorphin induction can be observed in vivo (Haberny and Carr 2005). These investigators report that treatment with 
$\mathrm{D}_{1}$ agonists stimulates dynorphin expression, whereas other experiments show that $\mathrm{D}_{1}$ activation also results in activation of CREB in the NAc (Liu and Graybiel 1998). Interestingly, this effect is relatively long lasting, with elevations in pCREB detectible in immunolabeled tissue for up to $24 \mathrm{~h}$ after a drug treatment. Increases in dynorphin expression are also long lasting, although they tend to have a slow onset and thus may not be evident in studies in which measurements are made shortly after a treatment (Knoll et al. 2011). These observations illustrate how CREB, once activated, can produce enduring alterations in transcriptional activity. Dynorphin has received increasing scrutiny for its potential involvement in addiction and mood disorders (Carlezon and Thomas 2009; Knoll and Carlezon 2010). As addressed below, the dynamics of CREB activation and dynorphin expression have immediate relevance to conditions like psychostimulant addiction in which repeated exposure to amphetamine or cocaine causes elevations in NAc DA.

\section{BEHAVIORAL CONSEQUENCES OF CREB ACTIVATION AND DYNORPHIN INDUCTION}

Acute treatment with either cocaine or morphine elevates the activity of adenylate cyclase and PKA in numerous brain structures (Terwilliger et al. 1991). One area of anatomical overlap in these effects is the NAc. This is likely due to the ability of both drugs to elevate extracellular concentrations of DA in this structure and activate the cAMP/PKA pathway via $G_{s}$-coupled $D_{1}$ receptors. As discussed above, the activity of PKA influences the activity of CREB, which can be expected to undergo phosphorylation following exposure to drugs of abuse. Indeed, after these initial reports of the effects of cocaine on PKA in the NAc, it was shown that amphetamine also elevates levels of pCREB in the NAc (Konradi et al. 1994; Turgeon et al. 1997). These findings, coupled with awareness of the essential role of the NAc in motivated behavior (Mogenson et al. 1980; Koob et al. 1989; Wise and Rompré 1989), stimulated interest in directly manipulating NAc CREB activity to determine its influence on drug seeking and reward. This was achieved using a combination of genetic engineering and behavioral pharmacology.

Viral vector-induced elevations of CREB within the NAc shell cause fundamental changes in the motivational properties of cocaine: rats avoid environmental cues that were previously paired with low doses of the drug (i.e., aversion), and are less sensitive to the rewarding effects of the drug at higher doses (i.e., anhedonia) (Carlezon et al. 1998). Potential explanations for these effects are that elevated CREB in the NAc enhances the anxiogenic effects of cocaine or somehow reduces the strength or duration of cocaine reward, which at low doses might result in an acute withdrawal state that becomes associated with the drug chamber in place conditioning studies. CREBmediated reductions in cocaine reward together with increases in aversive or stressful withdrawal signs might help to explain why the same viral vector treatment causes increases in cocaine intake in a drug self-administration paradigm (Larson et al. 2011), reflecting negative reinforcing effects (Koob and Le Moal 2008). Importantly, CREB overexpression in the NAc increases local levels of prodynorphin mRNA, and pretreatment with the long-acting KOR antagonist nor-binaltorphimine (norBNI) restores the rewarding effects of cocaine (Carlezon et al. 1998). Mirroring the effects of CREB, viral constructs encoding a dominant-negative CREB (mCREB) can enhance sensitivity to cocaine, conditioning a place preference at lower doses than those effective in rats expressing only a control gene (Carlezon et al. 1998). Cocaine reward is also enhanced in transgenic mice that inducibly overexpress $\mathrm{MCREB}$ in basal forebrain (Chen et al. 1998; Dinieri et al. 2009). In these mice, occluding basal CREB activity further potentiates the reward-enhancing effects of cocaine on electrical brain stimulation in the intracranial self-stimulation (ICSS) paradigm. In addition, mCREB-overexpressing mice also show reduced sensitivity to the depressive effects of the KOR agonist U50488 (Dinieri et al. 2009) - an agent that mimics dynorphin actions at KORs-providing further evidence that elevated CREB in NAc is associated with 
J.W. Muschamp and W.A. Carlezon, Jr.

an aversive state that might contribute to place aversions or increased drug self-administration in paradigms in which animals can control drug intake. Regardless, these studies suggest that CREB-regulated increases in dynorphin within the NAc have profound consequences for behavior, particularly in animal models used to study addiction.

Just as psychostimulants activate CREB in the NAc, they also increase the expression of dynorphin in this (and related) regions. This effect is apparent in rodents (Hurd et al. 1992), as well as in postmortem tissue from humans with a history of cocaine use and detectible blood cocaine levels at time of autopsy (Hurd and Herkenham 1993). Elevated NAc dynorphin may be conceptualized as a compensatory adaptation that modulates psychostimulant-induced DA release (see below) (Koob and Le Moal 2008). Given the relative stability of pCREB and dynorphin, levels of these molecules may remain elevated well past the drug exposure that elicited their formation. Because dynorphin induces dysphoria and anergia, its presence after the offset of the acute euphoric effects of psychostimulants may be responsible for the negative affect associated with drug withdrawal. Data from rodent place conditioning experiments support this view (Pliakas et al. 2001). In this report, rats were placed in a place conditioning apparatus for 15 min immediately following a low dose of cocaine. This time window captured the initial rewarding phase of cocaine and conditioned a preference for the drug-paired side of the apparatus. Placing rats in the apparatus $1 \mathrm{~h}$ after cocaine injection captured the offset of drug action and the onset of drug withdrawal, consequently producing place aversions that were equal in magnitude to those produced by overexpression of CREB, which increases dynorphin expression within NAc (Carlezon et al. 1998). Importantly, aversions to cocaine withdrawal were blocked by occluding NAc CREB function by overexpressing mCREB, which reduces dynorphin expression within this structure (Carlezon et al. 1998). Elevation of CREB also causes an increase in depressivelike behavior in the forced swim test - an effect mimicked by cocaine withdrawal (Potter et al.
2011) - that is blocked by KOR antagonists, again implicating elevated dynorphin (Pliakas et al. 2001). As predicted, attenuation of CREB activity by mCREB produced opposite effects, in this case an antidepressant-like phenotype that has been subsequently verified in other reports using comparable methods (Newton et al. 2002).

Given systemically, KOR agonists are aversive in humans, producing dysphoria and anxiety (Pfeiffer et al. 1986; Walsh et al. 2001). In rodents, central administration of KOR agonists into the NAc establishes conditioned place aversions (Bals-Kubik et al. 1993). Because brain stimulation reward is nonsatiating and not confounded by drug effects on learning and memory, ICSS provides an excellent method for measuring the contribution of the KOR system to basal function of brain reward circuitry in "real time" (Carlezon and Chartoff 2007). When given to rodents performing ICSS, KOR agonists reliably increase reward thresholds, indicating anhedonia (Todtenkopf et al. 2004; Carlezon et al. 2006). This effect originates in the NAc, where infusions of the KOR agonist U50488 also elevate ICSS thresholds (Muschamp et al. 2011). Surprisingly, systemically administered KOR antagonists do not have the opposite effect of decreasing reward thresholds (Potter et al. 2011). This suggests that any tonic dynorphin transmission does not strongly contribute to basal mood state. Instead, it seems likely that dynorphin is released phasically, as is common with peptide neuromodulators, and in response to strong extrinsic stimuli.

There is considerable evidence demonstrating that dynorphin and KOR systems mediate aversive effects that produce depressive-like effects on their own and decrease the impact of other types of reward, including psychostimulants. For example, KOR agonists can disrupt the ability of cocaine to condition a place preference (Crawford et al. 1995). In instrumental procedures used to measure drug reward, acute KOR activation produces dosedependent reductions in cocaine self-administration and blocks drug-primed reinstatement of cocaine or amphetamine self-administration (Glick et al. 1995; Schenket al. 1999; Morani et al. 2009). Finally, KOR agonists can attenuate the 
rewarding effects of cocaine as measured by the ICSS test in mice and rats (Tomasiewicz et al. 2008). The ability of KOR agonists to offset the rewarding effects of psychostimulants might appear to be a useful therapeutic mechanism, although these drugs exert broader effects on the function of brain reward systems that make this approach problematic.

Together, these data indicate that drug exposure activates CREB in the NAc, which subsequently elevates dynorphin expression within this region. Dynorphin transmission appears to mediate negative effects associated with drug withdrawal that can occasion further drug taking as a means of staving off the aversive symptoms of withdrawal. In this model, psychostimulant addiction is maintained in large part by negative reinforcement (Koob and Le Moal 2008).

Psychological stressors are another class of stimuli that increase dynorphin activity in the NAc. Dynorphin immunoreactivity in the NAc increases following both immobilization and footshock stress (Shirayama et al. 2004). In addition, forced swim stress elevates prodynorphin mRNA in the NAc (Chartoff et al. 2009). When footshock is used to condition a place aversion, this effect is absent in prodynorphin knockout mice, suggesting that it is not simply expression, but also dynorphin transmission that is critical for encoding negative effects associated with noxious stressors (Land et al. 2008). As noted above, these same stressful stimuli also activate CREB in the NAc (Pliakas et al. 2001; Muschamp et al. 2011), strongly implicating it as an important mediator of stress-induced dynorphin expression. Withdrawal from drugs of abuse may also serve as a stressor that can elevate dynorphin and KOR systems in the NAc, but this possibility needs to be tested more explicitly in the future.

\section{CIRCUITRY INVOLVED IN THE EFFECTS OF CREB AND DYNORPHIN ON DRUG REWARD}

The sections above have focused on the cellular and molecular mechanisms by which CREB and dynorphin are believed to influence affect and behaviors associated with animal models of psychostimulant addiction. If this mechanism indeed functions in a negative feedback capacity to homeostatically limit excess striatal DA resulting from drug exposure, how does this process influence at a neural systems level? Below are briefly discussed the circuitry on which CREB and dynorphin act to influence mood and drug-taking behavior.

In the dorsal striatum, MSNs that express $\mathrm{D}_{1}$ receptors and dynorphin, and that project to the substantia nigra (direct pathway) have long been viewed as a potential negative feedback mechanism that can modulate forebrain DA transmission (Gerfen and Surmeier 2011). This anatomical arrangement is also apparent in the ventral striatum and NAc, where $\mathrm{D}_{1}$-dynorphin-expressing neurons project to the ventral tegmental area (VTA) (Fig. 3). It is well established that systemic administration of KOR antagonists reduces basal as well as cocaineevoked DA levels in NAc and dorsal striatum (Spanagel et al. 1990; Maisonneuve et al. 1994; Carlezon et al. 2006). Surprisingly, this effect may not always be due to activation of KORs in the VTA and shows species differences (Devine et al. 1993; Margolis et al. 2006). Although KORs in the VTA attenuate the activity of NAcprojecting DA neurons in mice (Ford et al. 2006), the modulatory effect of KOR activation on NAc DA levels in rats seems to be due to hyperpolarization of KOR-expressing DA terminals by dynorphin released from recurrent collaterals of the direct pathway (Svingos et al. 1999). Indeed, reverse dialysis of dynorphin itself into NAc reduces local extracellular DA levels (Donzanti et al. 1992; Zhang et al. 2004). As noted in the introduction, NAc DA is intimately linked to reward and behavioral activation. As such, reductions in NAc DA that result from KOR activation may be necessary for the anhedonia and anergia experienced during withdrawal from psychostimulant use.

A second neuroadaptation that may contribute to the aversive effects of psychostimulant withdrawal involves the ability of CREB to increase the excitability of MSNs in the NAc. This increased excitability would favor the release of peptides like dynorphin from neurons of the 
J.W. Muschamp and W.A. Carlezon, Jr.

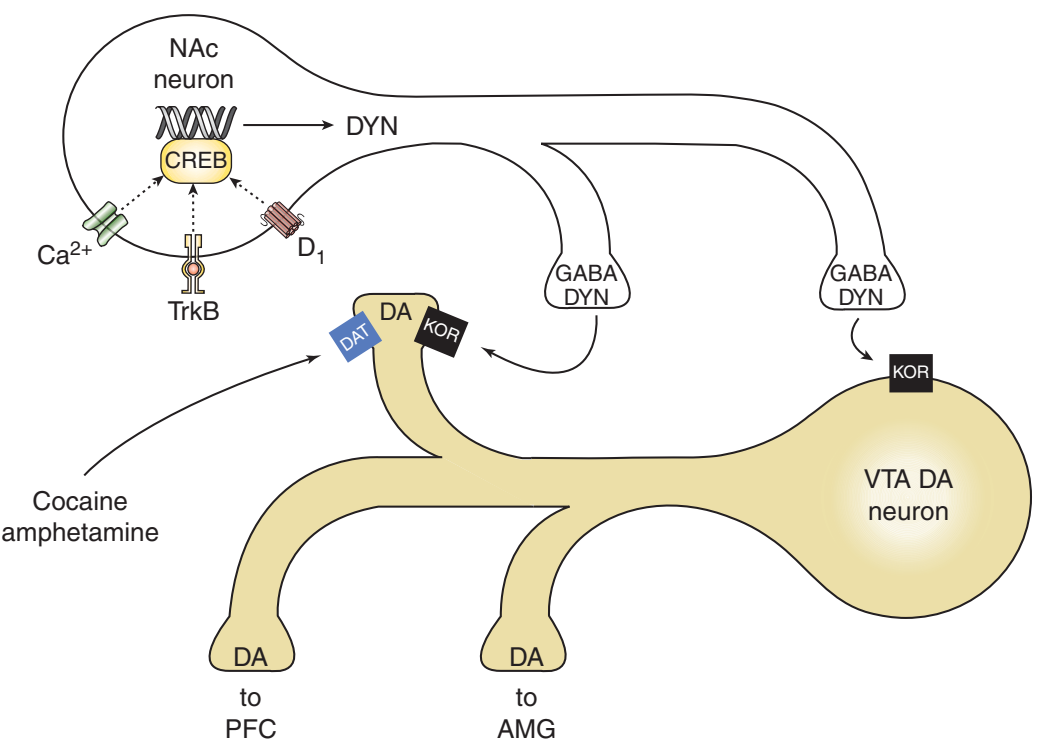

Figure 3. Simplified depiction of the mesolimbic dopamine (DA) feedback circuit in which psychostimulants and CREB exert key effects. Psychostimulants trigger activation of CREB in the GABAergic neurons of the NAc via indirect actions on receptors (e.g., $\mathrm{D}_{1}$, TrkB) and/or channels that gate calcium $\left(\mathrm{Ca}^{2+}\right)$. CREB-mediated increases in dynorphin (DYN) expression reduce release of DA by acting on inhibitory $\kappa$ opioid receptors (KORs) located on DA terminals in the NAc and/or VTA cell bodies. The inhibitory effect of DYN in VTA would also be expected to influence DA transmission in prefrontal cortex (PFC), amygdala (AMG), and other structures that receive projections from this region.

direct pathway, and, as described, depress levels of NAc DA. Reduced DA can be predicted to disinhibit $\mathrm{D}_{2}$-expressing striatopallidal neurons within the indirect pathway. Previous work suggests that the inhibition of this pathway encodes the rewarding effects of DA, and its stimulation may produce anhedonia or dysphoria (Carlezon et al. 1995; Durieux et al. 2009; Lobo et al. $2010)$. Broad ( $~ 75 \%)$ increases in MSN population activity are associated with aversive stimuli (Roitman et al. 2005; Wheeler et al. 2008; Wheeler and Carelli 2009), as well as behavioral inhibition (Ghazizadeh et al. 2012). We propose that activation of CREB following repeated drug exposure or stress results in NAc hyperexcitability. This phenomenon underlies a generalized dysregulation of brain reward systems that can play a role in addiction and comorbid psychiatric illness (Carlezon and Thomas 2009). Treatments that can normalize excitability within the NAc may be therapeutic for conditions involving dysregulation of motivation.

\section{IMPLICATIONS FOR TREATMENT}

As described in the other articles in this collection, concerted research efforts have yielded insight into the molecular mechanisms of abused drugs and the neurobiology of addiction. Despite a number of promising leads (Kampman 2010; Olive et al. 2012), these advances have not yet translated into highly effective pharmacotherapies. This problem has special relevance to methamphetamine and cocaine addiction, for which there are currently no U.S. Food and Drug Administration-approved medications. Although only a relatively modest percentage of people who try psychostimulants will become regular users or addicts, the absolute number of those who do is significant, with a worldwide market for cocaine and amphetamine of between 28 and 77 million users (Degenhardt and Hall 2012). Also significant are the costs to those addicted to psychostimulants, and in turn, to their communities, and society at large. 
These statistics reemphasize the importance and urgency of seeking novel, effective treatments for psychostimulant addiction to help individual users achieve abstinence, and to reduce the global drug market, mitigating its social costs.

The fact that CREB is expressed ubiquitously in the brain, together with its involvement in other important neural processes (e.g., learning and memory) and the lack of multiple isoforms that show differential patterns of expression in the central nervous system, make it a difficult target for small molecule therapeutics (Carlezon et al. 2005). A particularly salient illustration of this principle is BDNF, a neurotrophic factor that is regulated by CREB (Shieh et al. 1998; Tao et al. 1998). Whereas BDNF within the hippocampus plays a crucial role in stress resistance and antidepressant actions (Schmidt and $\mathrm{Du}-$ man 2007), it paradoxically promotes prodepressive effects via its actions in the NAc (Berton et al. 2006). The use of therapeutic agents that broadly target CREB function with the intention of enhancing BDNF function in hippocampus could have unintended consequences in the NAc that exacerbate illness. Instead, drug development efforts may be more fruitful if focused on the intracellular cascades that activate CREB, or other gene products induced by CREB that are responsible for the deleterious effects of chronic psychostimulant exposure. In this respect, KORs may be a useful target for novel therapeutic agents. Reports describing the antidepressantlike effects of KOR antagonists began appearing almost a decade ago (Pliakas et al. 2001; Newton et al. 2002; Mague et al. 2003; Beardsley et al. 2005). These agents also have acute anxiolytic and anti-fear effects (Knoll et al. 2007). In the context of addiction, KOR antagonists block cocaine craving (Beardsley et al.2005), as well as the motivational aspect of cocaine and nicotine withdrawal (Jackson et al. 2010; Chartoff et al. 2012). The common link among all of these findings may be a unique ability of KOR antagonists to block stress: the stress of forced swimming, novel environments, footshock, and drug withdrawal. Although the mechanisms by which KOR antagonist block stress are not currently understood, they may involve interactions with CRF (corticotropin-releasing factor) systems
(Land et al. 2008), which are thought to play a key role in the maintenance of addictive behavior (Koob 2010; Wee and Koob 2010). KORs are widely distributed in the brain (Mansour et al. 1994), and brain areas including the NAc (Pliakas et al. 2001; Newton et al. 2002), amygdala (Bruchas et al. 2009; Knoll et al. 2011), and dorsal raphe nucleus (Bruchas et al. 2011) have been implicated in the antistress effects of KOR antagonists; unlike the case of BDNF, however, the effects of KOR antagonists in all of these regions appears to be uniformly therapeutic. It is also important to point out that KOR agonists may also have some utility in treating addiction by virtue of their ability to decrease the rewarding effects of drugs of abuse (Negus et al. 1997; Tomasiewicz et al. 2008), which might target other aspects of the addicted state (Wise 2008), although these agents are poorly tolerated in humans (Pfeiffer et al. 1986). Partial KOR agonists may provide the potentially beneficial effects of both KOR antagonists and agonists in the context of addiction. Regardless, in light of the broad effects of CREB on multiple target genes that are potentially involved in addiction, multimodal treatment may be necessary to address multiple harmful neuroadaptations caused by chronic drug exposure.

\section{CONCLUSION}

Tracing the effects of psychostimulants from the synapse to the nucleus has led to a model of addiction in which problem drug use is maintained by the negative reinforcing effects of relieving drug withdrawal. As described above, CREB and the CREB-regulated target gene prodynorphin play significant roles in the aversive drug withdrawal state. As additional molecular targets of CREB in other brain areas are identified and their contribution to drug seeking is characterized, new treatment strategies may become evident. The work described in this article may provide a template for these future endeavors.

\section{ACKNOWLEDGMENTS}

This research is funded by grants from the $\mathrm{Na}$ tional Institutes of Health (F32DA026250 to 
J.W. Muschamp and W.A. Carlezon, Jr.

J.W.M., and R01MH063266 to W.A.C.). Dr. Muschamp reports no biomedical financial interests or potential conflicts of interest. Dr. Carlezon discloses that he and McLean Hospital are co-owners of a U.S. patent claiming the use of $\kappa$ opioid receptor antagonists in the treatment of depression.

\section{REFERENCES}

Altarejos JY, Montminy M. 2011. CREB and the CRTC coactivators: Sensors for hormonal and metabolic signals. Nat Rev Mol Cell Biol 12: 141-151.

Bals-Kubik R, Ableitner A, Herz A, Shippenberg TS. 1993. Neuroanatomical sites mediating the motivational effects of opioids as mapped by the conditioned place preference paradigm in rats. J Pharmacol Exp Ther 264: 489-495.

Bannister AJ, Kouzarides T. 1996. The CBP co-activator is a histone acetyltransferase. Nature 384: 641-643.

Beardsley PM, Howard JL, Shelton KL, Carroll FI. 2005 Differential effects of the novel $\kappa$ opioid receptor antagonist, JDTic, on reinstatement of cocaine-seeking induced by footshock stressors vs cocaine primes and its antidepressant-like effects in rats. Psychopharmacology (Berl) 183: 118-126.

Berton O, McClung CA, Dileone RJ, Krishnan V, Renthal W, Russo SJ, Graham D, Tsankova NM, Bolanos CA, Rios M, et al. 2006. Essential role of BDNF in the mesolimbic dopamine pathway in social defeat stress. Science 311: 864-868.

Brischoux F, Chakraborty S, Brierley DI, Ungless MA. 2009. Phasic excitation of dopamine neurons in ventral VTA by noxious stimuli. Proc Natl Acad Sci 106: 48944899.

Bruchas MR, Land BB, Lemos JC, Chavkin C. 2009. CRF1-R activation of the dynorphin/ $/$ opioid system in the mouse basolateral amygdala mediates anxiety-like behavior. PLoS ONE 4: e8528.

Bruchas MR, Schindler AG, Shankar H, Messinger DI Miyatake M, Land BB, Lemos JC, Hagan CE, Neumaier JF, Quintana A, et al. 2011. Selective p38 $\alpha$ MAPK deletion in serotonergic neurons produces stress resilience in models of depression and addiction. Neuron 71: 498511.

Carlezon WA, Chartoff EH. 2007. Intracranial self-stimulation (ICSS) in rodents to study the neurobiology of motivation. Nat Protoc 2: 2987-2995.

Carlezon WA Jr, Thomas MJ. 2009. Biological substrates of reward and aversion: A nucleus accumbens activity hypothesis. Neuropharmacology 56 (Suppl 1): 122-132.

Carlezon WA Jr, Devine DP, Wise RA. 1995. Habit-forming actions of nomifensine in nucleus accumbens. Psychopharmacology (Berl) 122: 194-197.

Carlezon WA Jr, Thome J, Olson VG, Lane-Ladd SB, Brodkin ES, Hiroi N, Duman RS, Neve RL, Nestler EJ. 1998. Regulation of cocaine reward by CREB. Science 282: 2272-2275.

Carlezon WA Jr, Duman RS, Nestler EJ. 2005. The many faces of CREB. Trends Neurosci 28: 436-445.
Carlezon WA Jr, Beguin C, DiNieri JA, Baumann MH, Richards MR, Todtenkopf MS, Rothman RB, Ma Z, Lee DY, Cohen BM. 2006. Depressive-like effects of the $\kappa-$ opioid receptor agonist salvinorin A on behavior and neurochemistry in rats. J Pharmacol Exp Ther 316: 440-447.

Chambers RA, Bickel WK, Potenza MN. 2007. A scale-free systems theory of motivation and addiction. Neurosci Biobehav Rev 31: 1017-1045.

Chartoff EH, Papadopoulou M, MacDonald ML, Parsegian A, Potter D, Konradi C, Carlezon WA Jr. 2009. Desipramine reduces stress-activated dynorphin expression and CREB phosphorylation in NAc tissue. Mol Pharmacol 75: 704-712.

Chartoff E, Sawyer A, Rachlin A, Potter D, Pliakas A, Carlezon WA. 2012. Blockade of $\kappa$ opioid receptors attenuates the development of depressive-like behaviors induced by cocaine withdrawal in rats. Neuropharmacology 62: 167176.

Chavkin C, James IF, Goldstein A. 1982. Dynorphin is a specific endogenous ligand of the $\kappa$ opioid receptor. Science 215: 413-415.

Chen J, Kelz MB, Zeng G, Sakai N, Steffen C, Shockett PE, Picciotto MR, Duman RS, Nestler EJ. 1998. Transgenic animals with inducible, targeted gene expression in brain. Mol Pharmacol 54: 495-503.

Chrivia JC, Kwok RP, Lamb N, Hagiwara M, Montminy MR, Goodman RH. 1993. Phosphorylated CREB binds specifically to the nuclear protein CBP. Nature 365: 855-859.

Coffey SF, Dansky BS, Carrigan MH, Brady KT. 2000. Acute and protracted cocaine abstinence in an outpatient population: A prospective study of mood, sleep and withdrawal symptoms. Drug Alcohol Depend 59: 277-286.

Cole RL, Konradi C, Douglass J, Hyman SE. 1995. Neuronal adaptation to amphetamine and dopamine: Molecular mechanisms of prodynorphin gene regulation in rat striatum. Neuron 14: 813-823.

Conkright MD, Canettieri G, Screaton R, Guzman E, Miraglia L, Hogenesch JB, Montminy M. 2003. TORCs: Transducers of regulated CREB activity. Mol Cell 12: 413-423.

Covington HE III, Maze I, Sun H, Bomze HM, DeMaio KD, Wu EY, Dietz DM, Lobo MK, Ghose S, Mouzon E, et al. 2011. A role for repressive histone methylation in cocaine-induced vulnerability to stress. Neuron 71: 656670.

Crawford CA, McDougall SA, Bolanos CA, Hall S, Berger SP. 1995. The effects of the $\kappa$ agonist U-50,488 on cocaineinduced conditioned and unconditioned behaviors and Fos immunoreactivity. Psychopharmacology (Berl) 120: 392-399.

Daunais JB, Roberts DC, McGinty JF. 1995. Short-term cocaine self administration alters striatal gene expression. Brain Res Bull 37: 523-527.

Degenhardt L, Hall W. 2012. Extent of illicit drug use and dependence, and their contribution to the global burden of disease. Lancet 379: 55-70.

Devine DP, Leone P, Pocock D, Wise RA. 1993. Differential involvement of ventral tegmental $\mu, \delta$ and $\kappa$ opioid receptors in modulation of basal mesolimbic dopamine release: In vivo microdialysis studies. J Pharmacol Exp Ther 266: 1236-1246. 
Dinieri JA, Nemeth CL, Parsegian A, Carle T, Gurevich VV, Gurevich E, Neve RL, Nestler EJ, Carlezon WA Jr. 2009. Altered sensitivity to rewarding and aversive drugs in mice with inducible disruption of cAMP response element-binding protein function within the nucleus accumbens. J Neurosci 29: 1855-1859.

Dong Y, Green T, Saal D, Marie H, Neve R, Nestler EJ, Malenka RC. 2006. CREB modulates excitability of nucleus accumbens neurons. Nat Neurosci 9: 475-477.

Donzanti BA, Althaus JS, Payson MM, Von Voigtlander PF. 1992. $\kappa$ Agonist-induced reduction in dopamine release: Site of action and tolerance. Res Commun Chem Pathol Pharmacol 78: 193-210.

Durieux PF, Bearzatto B, Guiducci S, Buch T, Waisman A, Zoli M, Schiffmann SN, de Kerchove d'Exaerde A. 2009. D2R striatopallidal neurons inhibit both locomotor and drug reward processes. Nat Neurosci 12: 393-395.

Ferreri K, Gill G, Montminy M. 1994. The cAMP-regulated transcription factor CREB interacts with a component of the TFIID complex. Proc Natl Acad Sci 91: 1210-1213.

Ford CP, Mark GP, Williams JT. 2006. Properties and opioid inhibition of mesolimbic dopamine neurons vary according to target location. J Neurosci 26: 2788-2797.

Foulkes NS, Borrelli E, Sassone-Corsi P. 1991. CREM gene: Use of alternative DNA-binding domains generates multiple antagonists of cAMP-induced transcription. Cell 64: 739-749.

Gerfen CR, Surmeier DJ. 2011. Modulation of striatal projection systems by dopamine. Annu Rev Neurosci 34: 441-466.

Ghazizadeh A, Ambroggi F, Odean N, Fields HL. 2012. Prefrontal cortex mediates extinction of responding by two distinct neural mechanisms in accumbens shell. J Neurosci 32: 726-737.

Glick SD, Maisonneuve IM, Raucci J, Archer S. 1995. к Opioid inhibition of morphine and cocaine self-administration in rats. Brain Res 681: 147-152.

Gonzalez GA, Montminy MR. 1989. Cyclic AMP stimulates somatostatin gene transcription by phosphorylation of CREB at serine 133. Cell 59: 675-680.

Graham DL, Edwards S, Bachtell RK, DiLeone RJ, Rios M, Self DW. 2007. Dynamic BDNF activity in nucleus accumbens with cocaine use increases self-administration and relapse. Nat Neurosci 10: 1029-1037.

Groenewegen HJ, Wright CI, Beijer AV. 1996. The nucleus accumbens: Gateway for limbic structures to reach the motor system? Prog Brain Res 107: 485-511.

Haberny SL, Carr KD. 2005. Comparison of basal and D-1 dopamine receptor agonist-stimulated neuropeptide gene expression in caudate-putamen and nucleus accumbens of ad libitum fed and food-restricted rats. Brain Res Mol Brain Res 141: 121-127.

Hagiwara M, Alberts A, Brindle P, Meinkoth J, Feramisco J, Deng T, Karin M, Shenolikar S, Montminy M. 1992. Transcriptional attenuation following cAMP induction requires PP-1-mediated dephosphorylation of CREB. Cell 70: $105-113$.

Hagiwara M, Brindle P, Harootunian A, Armstrong R, Rivier J, Vale W, Tsien R, Montminy MR. 1993. Coupling of hormonal stimulation and transcription via the cyclic
AMP-responsive factor CREB is rate limited by nuclear entry of protein kinase A. Mol Cell Biol 13: 4852-4859.

Han W, Takamatsu Y, Yamamoto H, Kasai S, Endo S, Shirao T, Kojima N, Ikeda K. 2011. Inhibitory role of inducible cAMP early repressor (ICER) in methamphetamine-induced locomotor sensitization. PLoS ONE 6: e21637.

Hobert O, Carrera I, Stefanakis N. 2010. The molecular and gene regulatory signature of a neuron. Trends Neurosci 33: 435-445.

Hoebel BG, Monaco AP, Hernandez L, Aulisi EF, Stanley BG, Lenard L. 1983. Self-injection of amphetamine directly into the brain. Psychopharmacology (Berl) 81: 158163.

Hollander JA, Im HI, Amelio AL, Kocerha J, Bali P, Lu Q, Willoughby D, Wahlestedt C, Conkright MD, Kenny PJ. 2010. Striatal microRNA controls cocaine intake through CREB signalling. Nature 466: 197-202.

Huang YH, Lin Y, Brown TE, Han MH, Saal DB, Neve RL, Zukin RS, Sorg BA, Nestler EJ, Malenka RC, et al. 2008. CREB modulates the functional output of nucleus accumbens neurons: A critical role of $N$-methyl-D-aspartate glutamate receptor (NMDAR) receptors. J Biol Chem 283: $2751-2760$.

Hurd YL, Herkenham M. 1993. Molecular alterations in the neostriatum of human cocaine addicts. Synapse 13: 357-369.

Hurd YL, Brown EE, Finlay JM, Fibiger HC, Gerfen CR. 1992. Cocaine self-administration differentially alters mRNA expression of striatal peptides. Brain Res Mol Brain Res 13: 165-170.

Ikemoto S, Panksepp J. 1999. The role of nucleus accumbens dopamine in motivated behavior: A unifying interpretation with special reference to reward-seeking. Brain Res Brain Res Rev 31: 6-41.

Ikemoto S, Wise RA. 2004. Mapping of chemical trigger zones for reward. Neuropharmacology 47 (Suppl 1): 190-201.

Impey S, McCorkle SR, Cha-Molstad H, Dwyer JM, Yochum GS, Boss JM, McWeeney S, Dunn JJ, Mandel G, Goodman RH. 2004. Defining the CREB regulon: A genomewide analysis of transcription factor regulatory regions. Cell 119: 1041-1054.

Jackson DM, Anden NE, Dahlstrom A. 1975. A functional effect of dopamine in the nucleus accumbens and in some other dopamine-rich parts of the rat brain. Psychopharmacologia 45: 139-149.

Jackson KJ, Carroll FI, Negus SS, Damaj MI. 2010. Effect of the selective $\mathrm{\kappa}$-opioid receptor antagonist JDTic on nicotine antinociception, reward, and withdrawal in the mouse. Psychopharmacology (Berl) 210: 285-294.

Joseph MH, Datla K, Young AM. 2003. The interpretation of the measurement of nucleus accumbens dopamine by in vivo dialysis: The kick, the craving or the cognition? Neurosci Biobehav Rev 27: 527-541.

Kampman KM. 2010. What's new in the treatment of cocaine addiction? Curr Psychiatry Rep 12: 441-447.

Kauer JA, Malenka RC. 2007. Synaptic plasticity and addiction. Nat Rev Neurosci 8: 844-858.

Kee BL, Arias J, Montminy MR. 1996. Adaptor-mediated recruitment of RNA polymerase II to a signal-dependent activator. J Biol Chem 271: 2373-2375. 
J.W. Muschamp and W.A. Carlezon, Jr.

Kim TK, Hemberg M, Gray JM, Costa AM, Bear DM, Wu J, Harmin DA, Laptewicz M, Barbara-Haley K, Kuersten S, et al. 2010. Widespread transcription at neuronal activity-regulated enhancers. Nature 465: 182-187.

Knoll AT, Carlezon WA Jr. 2010. Dynorphin, stress, and depression. Brain Res 1314: 56-73.

Knoll AT, Meloni EG, Thomas JB, Carroll FI, Carlezon WA Jr. 2007. Anxiolytic-like effects of $\kappa$-opioid receptor antagonists in models of unlearned and learned fear in rats. J Pharmacol Exp Ther 323: 838-845.

Knoll AT, Muschamp JW, Sillivan SE, Ferguson D, Dietz DM, Meloni EG, Carroll FI, Nestler EJ, Konradi C, Carlezon WA Jr. 2011. $\kappa$ Opioid receptor signaling in the basolateral amygdala regulates conditioned fear and anxiety in rats. Biol Psychiatry 70: 425-433.

Kobierski LA, Wong AE, Srivastava S, Borsook D, Hyman SE. 1999. Cyclic AMP-dependent activation of the proenkephalin gene requires phosphorylation of CREB at serine-133 and a Src-related kinase. J Neurochem 73: 129-138.

Konradi C, Kobierski LA, Nguyen TV, Heckers S, Hyman SE. 1993. The cAMP-response-element-binding protein interacts, but Fos protein does not interact, with the proenkephalin enhancer in rat striatum. Proc Natl Acad Sci 90: 7005-7009.

Konradi C, Cole RL, Heckers S, Hyman SE. 1994. Amphetamine regulates gene expression in rat striatum via transcription factor CREB. J Neurosci 14: 5623-5634.

Koob GF. 2010. The role of CRF and CRF-related peptides in the dark side of addiction. Brain Res 1314: 3-14.

Koob GF, Le Moal M. 2008. Addiction and the brain antireward system. Annu Rev Psychol 59: 29-53.

Koob GF, Wall TL, Bloom FE. 1989. Nucleus accumbens as a substrate for the aversive stimulus effects of opiate withdrawal. Psychopharmacology (Berl) 98: 530-534.

Land BB, Bruchas MR, Lemos JC, Xu M, Melief EJ, Chavkin C. 2008. The dysphoric component of stress is encoded by activation of the dynorphin $\mathrm{\kappa}$-opioid system. J Neurosci 28: $407-414$.

Larson EB, Graham DL, Arzaga RR, Buzin N, Webb J, Green TA, Bass CE, Neve RL, Terwilliger EF, Nestler EJ, et al. 2011. Overexpression of CREB in the nucleus accumbens shell increases cocaine reinforcement in self-administering rats. J Neurosci 31: 16447-16457.

Liu FC, Graybiel AM. 1998. Region-dependent dynamics of cAMP response element-binding protein phosphorylation in the basal ganglia. Proc Natl Acad Sci 95: 47084713.

Lobo MK, Covington HE 3rd, Chaudhury D, Friedman AK, Sun H, Damez-Werno D, Dietz DM, Zaman S, Koo JW, Kennedy PJ, et al. 2010. Cell type-specific loss of BDNF signaling mimics optogenetic control of cocaine reward. Science 330: 385-390.

Louilot A, Gonzalez-Mora JL, Guadalupe T, Mas M. 1991. Sex-related olfactory stimuli induce a selective increase in dopamine release in the nucleus accumbens of male rats. A voltammetric study. Brain Res 553: 313-317.

Loweth JA, Singer BF, Baker LK, Wilke G, Inamine H, Bubula N, Alexander JK, Carlezon WA Jr, Neve RL, Vezina P. 2010. Transient overexpression of $\alpha-\mathrm{Ca}^{2+} /$ calmodulindependent protein kinase II in the nucleus accumbens shell enhances behavioral responding to amphetamine. J Neurosci 30: 939-949.

Mague SD, Pliakas AM, Todtenkopf MS, Tomasiewicz HC, Zhang Y, Stevens WC Jr, Jones RM, Portoghese PS, Carlezon WA Jr. 2003. Antidepressant-like effects of $\kappa$-opioid receptor antagonists in the forced swim test in rats. J Pharmacol Exp Ther 305: 323-330.

Maisonneuve IM, Archer S, Glick SD. 1994. U50,488, а к opioid receptor agonist, attenuates cocaine-induced increases in extracellular dopamine in the nucleus accumbens of rats. Neurosci Lett 181: 57-60.

Mansour A, Fox CA, Meng F, Akil H, Watson SJ. 1994. к 1 receptor mRNA distribution in the rat CNS: Comparison to $\kappa$ receptor binding and prodynorphin mRNA. Mol Cell Neurosci 5: 124-144.

Margolis EB, Lock H, Chefer VI, Shippenberg TS, Hjelmstad GO, Fields HL. 2006. к Opioids selectively control dopaminergic neurons projecting to the prefrontal cortex. Proc Natl Acad Sci 103: 2938-2942.

Mattson BJ, Bossert JM, Simmons DE, Nozaki N, Nagarkar D, Kreuter JD, Hope BT. 2005. Cocaine-induced CREB phosphorylation in nucleus accumbens of cocaine-sensitized rats is enabled by enhanced activation of extracellular signal-related kinase, but not protein kinase A. J Neurochem 95: 1481-1494.

Mayr B, Montminy M. 2001. Transcriptional regulation by the phosphorylation-dependent factor CREB. Nat Rev Mol Cell Biol 2: 599-609.

McClung CA, Nestler EJ. 2003. Regulation of gene expression and cocaine reward by CREB and $\triangle F$ FosB. Nat Neurosci 6: $1208-1215$.

Meredith GE. 1999. The synaptic framework for chemical signaling in nucleus accumbens. Ann NY Acad Sci 877: $140-156$.

Mogenson GJ, Jones DL, Yim CY. 1980. From motivation to action: Functional interface between the limbic system and the motor system. Prog Neurobiol 14: 69-97.

Molina CA, Foulkes NS, Lalli E, Sassone-Corsi P. 1993. Inducibility and negative autoregulation of CREM: An alternative promoter directs the expression of ICER, an early response repressor. Cell 75: 875-886.

Montminy MR, Bilezikjian LM. 1987. Binding of a nuclear protein to the cyclic-AMP response element of the somatostatin gene. Nature 328: 175-178.

Montminy MR, Sevarino KA, Wagner JA, Mandel G, Goodman RH. 1986. Identification of a cyclic-AMP-responsive element within the rat somatostatin gene. Proc Natl Acad Sci 83: 6682-6686.

Morani AS, Kivell B, Prisinzano TE, Schenk S. 2009. Effect of К-opioid receptor agonists U69593, U50488H, spiradoline and salvinorin A on cocaine-induced drug-seeking in rats. Pharmacol Biochem Behav 94: 244-249.

Muschamp JW, Van't Veer A, Parsegian A, Gallo MS, Chen M, Neve RL, Meloni EG, Carlezon WA Jr. 2011. Activation of CREB in the nucleus accumbens shell produces anhedonia and resistance to extinction of fear in rats. $J$ Neurosci 31: 3095-3103.

Negus SS, Mello NK, Portoghese PS, Lin CE. 1997. Effects of $\kappa$ opioids on cocaine self-administration by rhesus monkeys. J Pharmacol Exp Ther 282: 44-55. 
Newton SS, Thome J, Wallace TL, Shirayama Y, Schlesinger L, Sakai N, Chen J, Neve R, Nestler EJ, Duman RS. 2002. Inhibition of cAMP response element-binding protein or dynorphin in the nucleus accumbens produces an antidepressant-like effect. J Neurosci 22: 10883-10890.

Ogryzko VV, Schiltz RL, Russanova V, Howard BH, Nakatani Y. 1996. The transcriptional coactivators p300 and CBP are histone acetyltransferases. Cell 87: 953-959.

Okaty BW, Sugino K, Nelson SB. 2011. A quantitative comparison of cell-type-specific microarray gene expression profiling methods in the mouse brain. PLOS ONE 6: e16493.

Olive MF, Cleva RM, Kalivas PW, Malcolm RJ. 2012. Glutamatergic medications for the treatment of drug and behavioral addictions. Pharmacol Biochem Behav 100: 801-810.

Papai G, Weil PA, Schultz P. 2011. New insights into the function of transcription factor TFIID from recent structural studies. Curr Opin Genet Dev 21: 219-224.

Parsons LH, Smith AD, Justice JB Jr. 1991. Basal extracellular dopamine is decreased in the rat nucleus accumbens during abstinence from chronic cocaine. Synapse 9: 60-65.

Pennartz CM, Berke JD, Graybiel AM, Ito R, Lansink CS, van der Meer M, Redish AD, Smith KS, Voorn P. 2009. Corticostriatal interactions during learning, memory processing, and decision making. J Neurosci 29: 1283112838.

Pfeiffer A, Brantl V, Herz A, Emrich HM. 1986. Psychotomimesis mediated by $\kappa$ opiate receptors. Science 233 774-776.

Pliakas AM, Carlson RR, Neve RL, Konradi C, Nestler EJ, Carlezon WA Jr. 2001. Altered responsiveness to cocaine and increased immobility in the forced swim test associated with elevated cAMP response element-binding protein expression in nucleus accumbens. J Neurosci 21: 7397-7403.

Potter DN, Damez-Werno D, Carlezon WA Jr, Cohen BM, Chartoff EH. 2011. Repeated exposure to the $\kappa$-opioid receptor agonist salvinorin A modulates extracellular signal-regulated kinase and reward sensitivity. Biol Psychiatry 70: 744-753.

Radhakrishnan I, Perez-Alvarado GC, Parker D, Dyson HJ, Montminy MR, Wright PE. 1997. Solution structure of the KIX domain of CBP bound to the transactivation domain of CREB: A model for activator:coactivator interactions. Cell 91: 741-752.

Redgrave P, Vautrelle N, Reynolds JN. 2011. Functional properties of the basal ganglia's re-entrant loop architecture: Selection and reinforcement. Neuroscience 198: $138-151$.

Robertson MW, Leslie CA, Bennett JP Jr. 1991. Apparent synaptic dopamine deficiency induced by withdrawal from chronic cocaine treatment. Brain Res 538: 337-339.

Roitman MF, Stuber GD, Phillips PE, Wightman RM, Carelli RM. 2004. Dopamine operates as a subsecond modulator of food seeking. J Neurosci 24: 1265-1271.

Roitman MF, Wheeler RA, Carelli RM. 2005. Nucleus accumbens neurons are innately tuned for rewarding and aversive taste stimuli, encode their predictors, and are linked to motor output. Neuron 45: 587-597.
Schenk S, Partridge B, Shippenberg TS. 1999. U69593, a кopioid agonist, decreases cocaine self-administration and decreases cocaine-produced drug-seeking. Psychopharmacology (Berl) 144: 339-346.

Schmidt HD, Duman RS. 2007. The role of neurotrophic factors in adult hippocampal neurogenesis, antidepressant treatments and animal models of depressive-like behavior. Behav Pharmacol 18: 391-418.

Schultz W. 2007. Multiple dopamine functions at different time courses. Annu Rev Neurosci 30: 259-288.

Shaywitz AJ, Greenberg ME. 1999. CREB: A stimulus-induced transcription factor activated by a diverse array of extracellular signals. Annu Rev Biochem 68: 821-861.

Shieh PB, Hu SC, Bobb K, Timmusk T, Ghosh A. 1998. Identification of a signaling pathway involved in calcium regulation of BDNF expression. Neuron 20: 727-740.

Shirayama Y, Ishida H, Iwata M, Hazama GI, Kawahara R, Duman RS. 2004. Stress increases dynorphin immunoreactivity in limbic brain regions and dynorphin antagonism produces antidepressant-like effects. J Neurochem 90: $1258-1268$.

Simpson JN, McGinty JF. 1995. Forskolin induces preproenkephalin and preprodynorphin mRNA in rat striatum as demonstrated by in situ hybridization histochemistry. Synapse 19: 151-159.

Spanagel R, Herz A, Shippenberg TS. 1990. The effects of opioid peptides on dopamine release in the nucleus accumbens: An in vivo microdialysis study. J Neurochem 55: $1734-1740$.

Sun P, Enslen H, Myung PS, Maurer RA. 1994. Differential activation of CREB by $\mathrm{Ca}^{2+} /$ calmodulin-dependent protein kinases type II and type IV involves phosphorylation of a site that negatively regulates activity. Genes Dev 8: 2527-2539.

Svingos AL, Colago EE, Pickel VM. 1999. Cellular sites for dynorphin activation of $\kappa$-opioid receptors in the rat nucleus accumbens shell. J Neurosci 19: 1804-1813.

Swendsen J, Conway KP, Degenhardt L, Glantz M, Jin R, Merikangas KR, Sampson N, Kessler RC. 2010. Mental disorders as risk factors for substance use, abuse and dependence: Results from the 10-year follow-up of the National Comorbidity Survey. Addiction 105: 11171128.

Tao X, Finkbeiner S, Arnold DB, Shaywitz AJ, Greenberg ME. 1998. $\mathrm{Ca}^{2+}$ influx regulates BDNF transcription by a CREB family transcription factor-dependent mechanism. Neuron 20: 709-726.

Terwilliger RZ, Beitner-Johnson D, Sevarino KA, Crain SM, Nestler EJ. 1991. A general role for adaptations in Gproteins and the cyclic AMP system in mediating the chronic actions of morphine and cocaine on neuronal function. Brain Res 548: 100-110.

Tidey JW, Miczek KA. 1996. Social defeat stress selectively alters mesocorticolimbic dopamine release: An in vivo microdialysis study. Brain Res 721: 140-149.

Todtenkopf MS, Marcus JF, Portoghese PS, Carlezon WA Jr. 2004. Effects of $\kappa$-opioid receptor ligands on intracranial self-stimulation in rats. Psychopharmacology (Berl) 172: $463-470$.

Tomasiewicz HC, Todtenkopf MS, Chartoff EH, Cohen BM, Carlezon WA Jr. 2008. The к-opioid agonist U69,593 
J.W. Muschamp and W.A. Carlezon, Jr.

blocks cocaine-induced enhancement of brain stimulation reward. Biol Psychiatry 64: 982-988.

Turgeon SM, Pollack AE, Fink JS. 1997. Enhanced CREB phosphorylation and changes in c-Fos and FRA expression in striatum accompany amphetamine sensitization. Brain Res 749: 120-126.

Volkow ND, Fowler JS, Wang GJ, Baler R, Telang F. 2009. Imaging dopamine's role in drug abuse and addiction. Neuropharmacology 56 (Suppl 1): 3-8.

Voorn P, Vanderschuren LJ, Groenewegen HJ, Robbins TW, Pennartz CM. 2004. Putting a spin on the dorsal-ventral divide of the striatum. Trends Neurosci 27: 468-474.

Wadzinski BE, Wheat WH, Jaspers S, Peruski LF Jr, Lickteig RL, Johnson GL, Klemm DJ. 1993. Nuclear protein phosphatase 2A dephosphorylates protein kinase A-phosphorylated CREB and regulates CREB transcriptional stimulation. Mol Cell Biol 13: 2822-2834.

Walsh SL, Strain EC, Abreu ME, Bigelow GE. 2001. Enadoline, a selective $\kappa$ opioid agonist: Comparison with butorphanol and hydromorphone in humans. Psychopharmacology (Berl) 157: 151-162.

Weddington WW, Brown BS, Haertzen CA, Cone EJ, Dax EM, Herning RI, Michaelson BS. 1990. Changes in mood, craving, and sleep during short-term abstinence reported by male cocaine addicts. A controlled, residential study. Arch Gen Psychiatry 47: 861-868.

Wee S, Koob GF. 2010. The role of the dynorphin-к opioid system in the reinforcing effects of drugs of abuse. Psychopharmacology (Berl) 210: 121-135.

Wheeler RA, Carelli RM. 2009. Dissecting motivational circuitry to understand substance abuse. Neuropharmacology 56 (Suppl 1): 149-159.

Wheeler RA, Twining RC, Jones JL, Slater JM, Grigson PS, Carelli RM. 2008. Behavioral and electrophysiological indices of negative affect predict cocaine self-administration. Neuron 57: 774-785.

Wilkinson MB, Xiao G, Kumar A, LaPlant Q, Renthal W, Sikder D, Kodadek TJ, Nestler EJ. 2009. Imipramine treatment and resiliency exhibit similar chromatin regulation in the mouse nucleus accumbens in depression models. J Neurosci 29: 7820-7832.

Wise RA. 2004. Dopamine, learning and motivation. Nat Rev Neurosci 5: 483-494.

Wise RA. 2008. Dopamine and reward: The anhedonia hypothesis 30 years on. Neurotox Res 14: 169-183.

Wise RA, Rompré PP. 1989. Brain dopamine and reward. Annu Rev Psychol 40: 191-225.

Witten IB, Steinberg EE, Lee SY, Davidson TJ, Zalocusky KA, Brodsky M, Yizhar O, Cho SL, Gong S, Ramakrishnan C, et al. 2011. Recombinase-driver rat lines: Tools, techniques, and optogenetic application to dopamine-mediated reinforcement. Neuron 72: 721-733.

Yamamoto KK, Gonzalez GA, Biggs WH III, Montminy MR. 1988. Phosphorylation-induced binding and transcriptional efficacy of nuclear factor CREB. Nature 334: 494-498.

Zhang Y, Butelman ER, Schlussman SD, Ho A, Kreek MJ. 2004. Effect of the endogenous $\kappa$ opioid agonist dynorphin $\mathrm{A}(1-17)$ on cocaine-evoked increases in striatal dopamine levels and cocaine-induced place preference in C57BL/6J mice. Psychopharmacology (Berl) 172: 422-429.

Zhang X, Odom DT, Koo SH, Conkright MD, Canettieri G, Best J, Chen H, Jenner R, Herbolsheimer E, Jacobsen E, et al. 2005. Genome-wide analysis of cAMP-response element binding protein occupancy, phosphorylation, and target gene activation in human tissues. Proc Natl Acad Sci 102: $4459-4464$. 


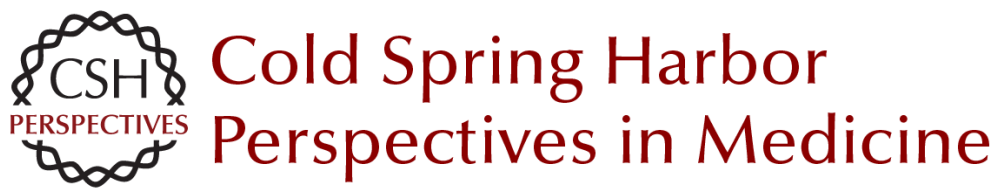

\section{Roles of Nucleus Accumbens CREB and Dynorphin in Dysregulation of Motivation}

John W. Muschamp and William A. Carlezon, Jr.

Cold Spring Harb Perspect Med 2013; doi: 10.1101/cshperspect.a012005 originally published online January 4, 2013

\section{Subject Collection Addiction}

Developments from Bulk Optogenetics to

Single-Cell Strategies to Dissect the Neural

Circuits that Underlie Aberrant Motivational States Jose Rodriguez-Romaguera, Vijay M.K. Namboodiri, Marcus L. Basiri, et al.

Consequences of Parental Opioid Exposure on Neurophysiology, Behavior, and Health in the Next Generations

Fair M. Vassoler and Mathieu E. Wimmer

Animal Models of the Behavioral Symptoms of Substance Use Disorders Louk J.M.J. Vanderschuren and Serge H. Ahmed

Translational Research in Nicotine Addiction Miranda L. Fisher, James R. Pauly, Brett Froeliger, et al.

Neonatal Opioid Withdrawal Syndrome (NOWS): A Transgenerational Echo of the Opioid Crisis Andrew E. Weller, Richard C. Crist, Benjamin C. Reiner, et al.

Impairment of Synaptic Plasticity by Cannabis, $\Delta^{\mathbf{9}}$ -THC, and Synthetic Cannabinoids Alexander F. Hoffman, Eun-Kyung Hwang and Carl R. Lupica

Drug-Evoked Synaptic Plasticity of Excitatory Transmission in the Ventral Tegmental Area Camilla Bellone, Michael Loureiro and Christian Lüscher

Opioid-Induced Molecular and Cellular Plasticity of Ventral Tegmental Area Dopamine Neurons Marie A. Doyle and Michelle S. Mazei-Robison
The Persistent Challenge of Developing Addiction

Pharmacotherapies

Sarah E. Swinford-Jackson, Charles P. O'Brien,

Paul J. Kenny, et al.

Opioid Modulation of the Gut-Brain Axis in Opioid-Associated Comorbidities

Li Zhang and Sabita Roy

Epigenetics of Drug Addiction Andrew F. Stewart, Sasha L. Fulton and lan Maze

Genetic Vulnerability to Opioid Addiction Brian Reed and Mary Jeanne Kreek

Glutamatergic Systems and Memory Mechanisms Underlying Opioid Addiction Jasper A. Heinsbroek, Taco J. De Vries and Jamie Peters

Mechanisms of Nicotine Addiction Marina R. Picciotto and Paul J. Kenny

Neural Substrates and Circuits of Drug Addiction Matthew W. Feltenstein, Ronald E. See and Rita A. Fuchs

The Role of the Central Amygdala in Alcohol Dependence Marisa Roberto, Dean Kirson and Sophia Khom

For additional articles in this collection, see http://perspectivesinmedicine.cshlp.org/cgi/collection/ 